原蓄

右肝静脈の肝外処理の可否と下大静脈勒帯切離の重要性について

国立がんセンター外科

幕内雅敏長谷川博山崎晋

\title{
SIGNIFICANCE OF DIVISION OF THE VENA CAVA LIGAMENT FOR EXTRAHEPATIC DISSECTION OF THE RIGHT HEPATIC VEIN
}

Masatoshi MAKUUCHI, Hiroshi HASEGAWA and Susumu YAMASAKI

Department of Hepatic Surgery, National Cancer Center Hospital

肝切除に際して右肝静脈を下大静脈流入部付近で切離する必要があるが，これを肝離 断前に肝外処理を行らか，肝離断中に肝内で処理するかについては議論がある。しかし 肝外処理が可能であれば，肝外処理を行った方が出血量も少なく安心して肝離断が行え る.

我々は昭和54年末に右肝静脈の肝外処理の秘訣は下大静脈靮帯の切離にあることに気 付き，昭和55年以降は意識してこれを切離することに努めた，その結果，昭和54年以前 の36例では 9 例（25\%）に肝外処理ができたにすぎなかったが，昭和55年以降の25例で は22例（88\%）で肝外処理に成功した。

肝静脈の処理に関して下大静脈勒帯の存在に論及した文献が見当らないので，肝切除 の際の右肝静脈の処理に関し, 若干の文献的考察を加えて報告した.

古引用語：肝切除術，右肝静脈，下大静脈勒帯

\section{I. 緒 言}

定型的肝右葉切除や右 3 区域切除術では，右肝静脈 を下大静脈流入部で切離する必要がある，右肝静脈の 切離は, 肝の離断に先立って行らべきか，あるいは肝 の離断の最終段階で行らべきかについては，以前より 議論のあるところである.肝静脈の下大静脈流入部は 心掝に近く，一度損傷すると大出血を招く危険がある ので, 同部の安全な処理は肝切除の一つの要とも言 べきのである.ところが実際に肝外処理が全例で可 能かについて論した文献は見当らず，また，同部の安 全で出血量の少ない処理法につき詳述した文献もな い. 著者らは, 昭和54年後半より同部の処理の要点は 下大静脈靶帯の確実な切離にあることに気付き，昭和 55年以降は高率に右肝静脈の肝外処理が可能になっ た。 そこで，右肝静脈を切除する術式で，どの程度肝 離断前に肝外で処理できたかについて調查し，肝外処 理の要点について報告する.
II. 下大静脈靬帯が肝切除時に下大静脈およU 右肝静脈に与える影整

下大静脈勒带は, 肝部下大静脈の肝静脈流入部付近 の背側に存し、肝右葉と左尾状葉とを結ぶ靯帯であ る1)(図 1)，下大静脈靶帯はかなり厚い線維性の結合

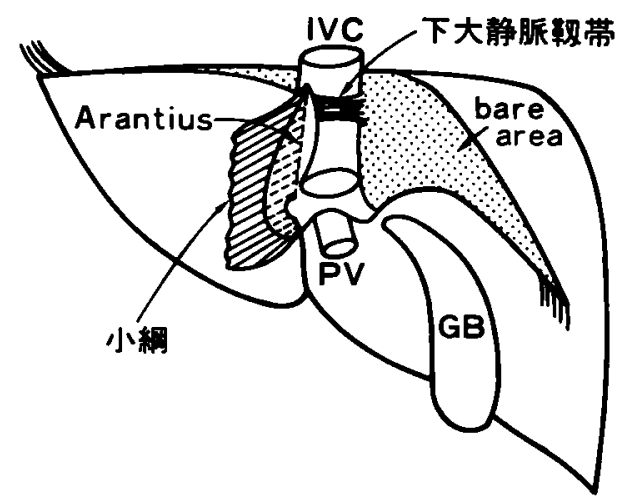

图1肝を背側から見た外䖝

IVC : 下大静脈, PV : 門脈, GB : 胆要 
織として認められる場合が多いが，はとんど粗性結合 織のみしか認められない例すある。.さて, 肝切除の際 には, 右三角勒帯おょび肝冠状勒帯を切離し, bare area 荆離して, 肝右葉を左方に脱転する. 肝右葉を 脱転すると右肝静脈流入部付近の肝部下大静脈は下大 静脈勒帯によって左側腹側に压排されることになる （図 2 ），短肝静脈を尾側から結禁切離して行くと，図 3 A に示すよらに下大静脈勒帯が蕗出され, 下大静脈 が下大静脈靬帯によって左側腹側に王排される. 右肝 静脈は下大静脈勒帯の内側に接して存在するので, 下 大静脈靯帯を切離すれば，右肝静脈の下大静脈流入部 右側壁が露出される（図3 B).

\section{III. 下大静脈靬带の切離法}

短肝静脈を尾側から切離して行くと下大静脈勒帯が 露出されてくるが，右肝静脈は下大静脈右側壁ととも に左側腹側に王排され，しかも両者が二枚の平行する 面となって接している。ここで，下大静脈勒帯を右肝 静脈と誤認して下大静脈前面を剥離して行くと,これ
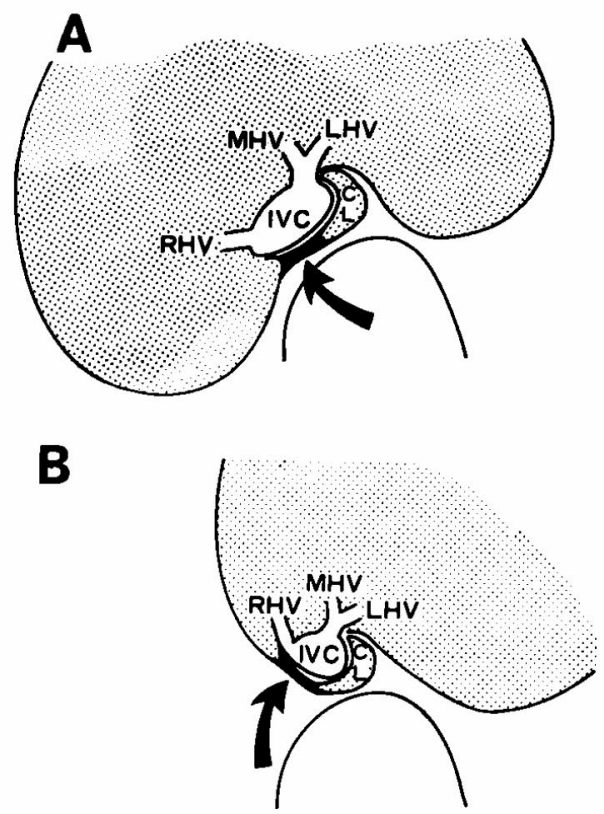

园 2 肝を尾侧から見た㯕断図

A 下大静脈墐带 (矢印) は肝右葉と左尾状葉の間 を結ふ勒带である。

B 肝右葉を脱転すると, 下大静脈鞄帯によって 下大静脈は左側腹側に圧排され，右肝静脈流入部で は右肝静脈と下大静脈鞄帯がほほ平行して走行す る。

RHV：右肝静脈, LHV：左肝静脈, CL：尾状葉, MHV：中肝静脈, IVC：下大静脈
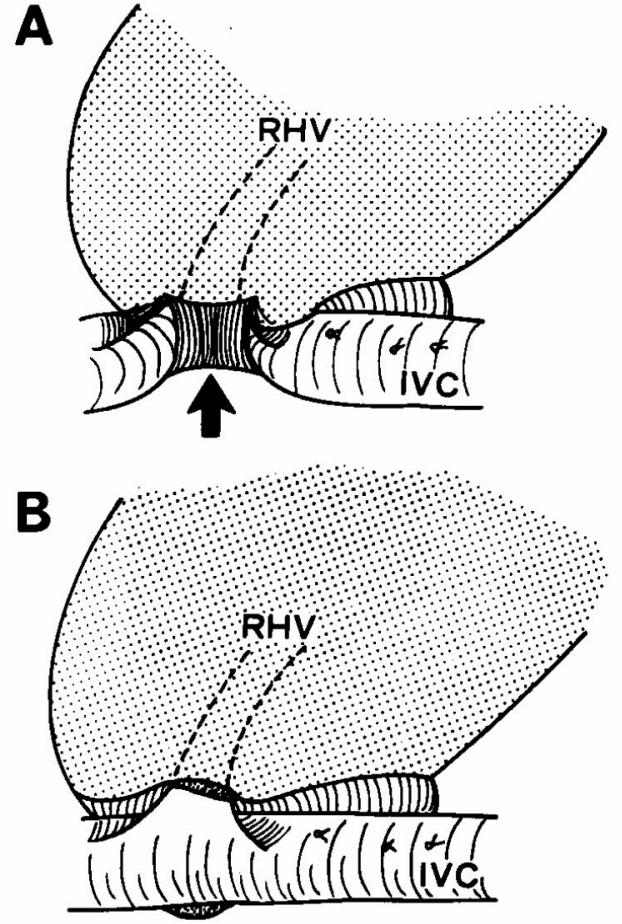

图3肝を脱転し右側から見た外㙽

A 短肝静脈を尾側から順に切離して行くと、下 大静脈勒带 (矢印) によって下大静脈が背側から王 排された状態となる。

B 下大静脈勒帯を切離すると右肝静脈流入部付 近の下大静脈右側壁が完全に露出され，下大静脈の 左側腹側への王排はなくなる。

RHV：右肝静脈, IVC：下大静脈

と重なる右肝静脈合流部の尾側端を穿破し，大出血を 招来することになる。そこで，下大静脈の右側壁に沿っ て, 下大静脈を軽く左方へ王排しながら下大静脈软带 を下大静脈から剩離すると，下大静脈勒带と下大觧脈 および右肝静脈右側壁との間に Kelly の鉜子を通すこ とができる（写真1）．Kellyが通れば，下大静脈䓪帯

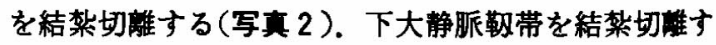
るのは短肝静脈がこの靱帯内を走行している例がある からである，下大静脈勒帯は写真1に示したすのより 幅の広い例があるが，その際は 2 度 3 度に分けて結禁 切離する. 下大静脈勒帯が完全に切離されると, 右肝 静脈，下大静脈，肝臓の間には粗な結合織をのこすの みであり、これを剝離して行くと右肝静脈の根部は容 易に露出される(写真了)。ささらに, 右肝静脈を切離䋖 合した後には，写真 4 に示すごとく，中肝静脈の根部 るまた容易に露出し得る.この部位までの豩離は右葉 


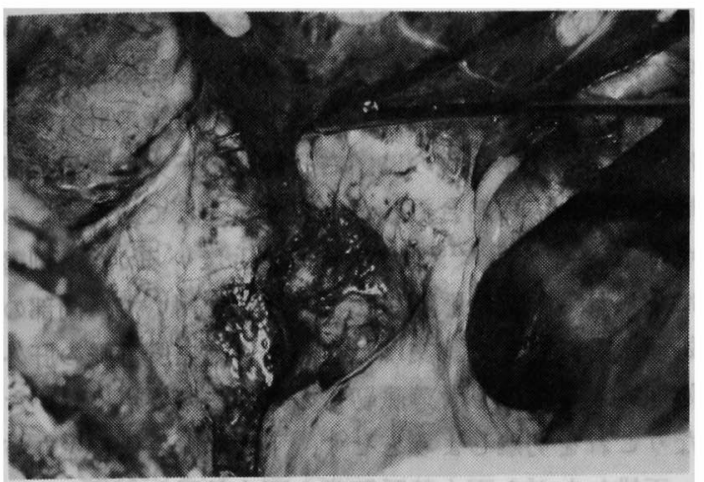

写真 1 Kelly の銝子を下大静脈靶带と下大静脈の 間に择入している。

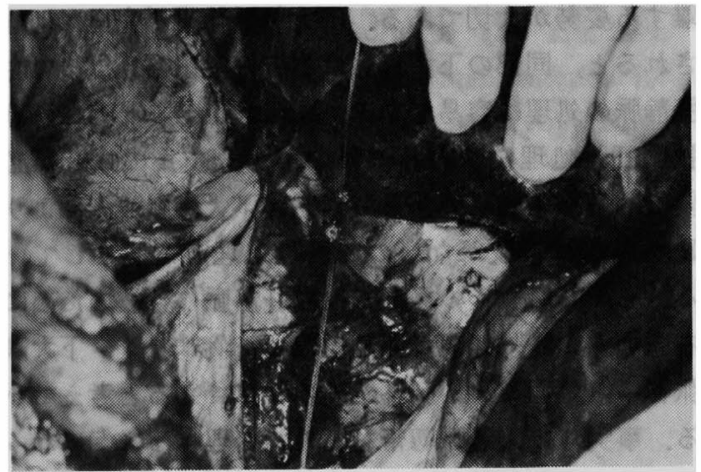

写真 2 下大静脈靯带を結梷切離したところである。

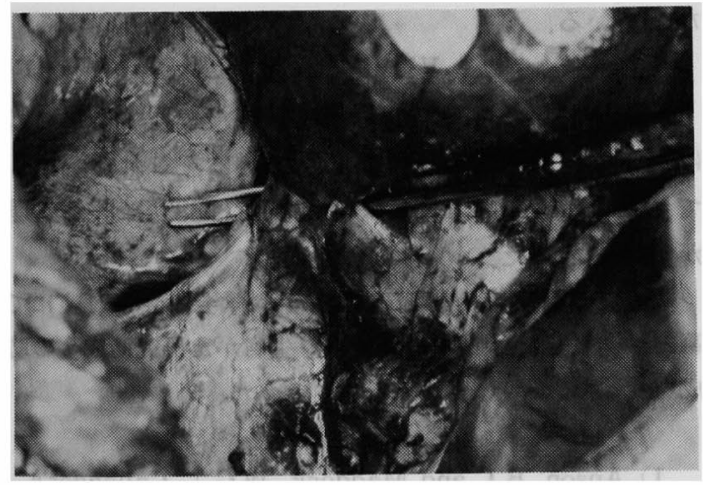

写真 3 Kelly の鉗子を右肝静脈の左側の下大静脈前 面に捅入している.すでに下大静脈勤帯が切離して あるので, 粗性結合織を剝離するのみで，この操作 は極めて容易である。

切除や右三区域切除を行う場合に必須である。

\section{IV. 対象书よU゙右肝静脈の肝外処理率}

昭和48年より昭和58年 6 月末日までに195例に対し 203回の肝切除術を施行した。このらち右肝静脈を根部

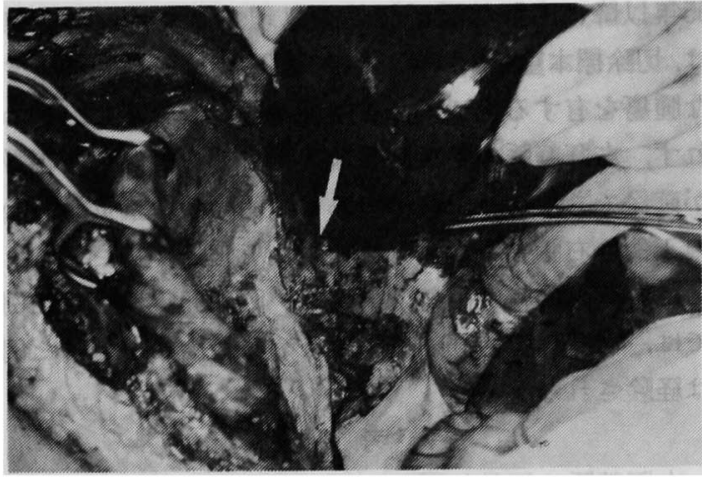

写真 4 肝部下大静脈の鹤睢操作終了時である.中 肝静脈と左肝静脈の根部 (矢印) むでが完全に露出 されている，血管敕合の要領で䋖合された，右肝静 脈の下大静脈流入部の縫合線か;, 中肝静脈の下方に みえている。

から切除する手訹は61例に行われた，内訳は，右三区 域切除35例, 右二区域切除23例, 下右肝静脈温存手術 3 例であった(表 1)。これらを対象として，右肝静脈 が肝外で処理されたか否かを検討した。

下大静脈鞄帯の切離が意図して行われていなかった 昭和54年末むでの36例では，9 例（25\%）が肝外で処 理されたにすぎなかった，昭和55年以降は短肝静脈を 下大静脈前面まで十分結禁切離することと下大静脈勒 帯を意識して結禁切離することによって25例中22例 （88\%）が肝外で右肝静脈が処理された（表 2）。昭和

表 1 右肝静脈全切除を要する症例 肝切除 195 例 203 回

$$
\frac{\left\{\begin{array}{lr}
\text { 右 } 3 \text { 区 域切除 } & 35 \text { 例 } \\
\text { 右 } 2 \text { 区 域切除 } & 23 \text { 例 } \\
\text { 下右肝静脈温存手術 } & 3 \text { 例 }
\end{array}\right.}{\text { 計 } 61 \text { 例 }}
$$

表 2 右肝静脈の肝外処理

\begin{tabular}{|c|c|cc|}
\hline 間 & 右肝髅眽切除例 & \multicolumn{2}{|c|}{ 肝外処理 } \\
\hline $1973 \sim 1979$ 年 & 36 & 9 & $25 \%$ \\
\hline $\begin{array}{r}1980 \sim 1983 \text { 年 } \\
6 \text { 月 }\end{array}$ & 25 & 22 & $88 \%$ \\
\hline
\end{tabular}

肝切除 195 例 203 回 
55年以降に右訮静脈が肝外で処理されなかった 3 例 は, 切除標本重量 $3,800 \mathrm{~g}, 3,400 \mathrm{~g}, 2,910 \mathrm{~g}$ と比較的大き な尰瘍を有する例で, 後腹膜腔からの脱転が十分行わ れず，右肝静脈の下大静脈流入部付近の良好なる視野 が確保できなかったためである，切除標本重量 $2,910 \mathrm{~g}$ の 1 例は右肺中下葉切除後の症例で腫湯が小さいわり には右葉の脱転が困難ですった，昭和55年以降の22例 では，右肝静脈の肝外処理のために，出血を生じた例 は経験されなかった。

\section{V. 考}

右肝静脈の肝外処理の可否については以前より議論 のあるところで，肝外処理をすべきであると言ら者と 肝離断の最終段階で行らべきであるとする者とに 2 分 されている. Couinaud ${ }^{2)}$, Bengmark ${ }^{3)}$, Longmire ら", Starzl 5 5), Adson 56), Ong ${ }^{7}$, Linder 5 ${ }^{8)}$ は肝外処理 を行らべきたと主張し, Kune ${ }^{9)}$, Brasfield ${ }^{10)}$, Fortner

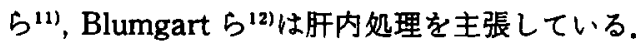

肝外処理を主張する Couinaud ${ }^{2)}$ 著書には肝内処 理の図も見られ，Longmire ${ }^{2)}$ 女右肝静脈の䟝離に際し 出血した場合はパックして出血をコントロールし，䏕 離断後に処理すると言 5. Linder ら 腫瓷が大きく右肝静脈の肝外処理が困難である場合は 肝内で処理すべきだと述べている，我々の症例です， 昭和55年以降 3 例の肝内処理例があるが，これらはい、

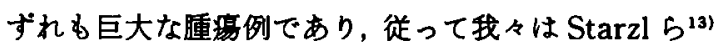
の主張を支持するものである.しかし, Blumgart ら は大きな腫瘍が存在する場合は, 定型的に肝部下大静 脈の尾侧から頭側への短肝静脈と右肝静脈の処理を注 意深く行らべきであると主張している. 巨大な腫煌例 で肝静脈を肝外処理すべきか肝内で処理すべきかは， 開創法之密接に関係しており，巨大腫瘍にもかかわら ず，肝右葉が後腹腹腔より脱転でき，肝部下大静脈付 近の良好な視野が得られるか否かにかかっている. 本 年我々が経験した切除標本重量 $5.500 \mathrm{~g}$ の肝細胞癌例 では，巨大な稙瘍にすかかわらず，右肝静脈の訮外処 理に成功している、我々は, 長谷川ら ${ }^{14)}$ が示した高位横 切開を右後腋窝線にまで広げ，これに加えて正中切開 を両側乳頭を結ぶ高さまで延長する皮切を行い, parasternotomyを必要に応じて行っている. 切除標本重 量 $2,000 \mathrm{~g}$ 以上と推定される肝上部の腫瘍では, 正中の 皮切を胸骨窝直下まで延ばして，全胸骨正中切開を加 え，横隔膜を正中で下大静脈裂口直上まで切開すれば， 右肝静脈の訮内処理を行った 3 症例です肝外処理が可 能であったと思われる。いずれにしても肝外処理を
行った方が肝離断中の出血を減少させることがでさる ので，出来るだけ肝外処理を追求すべきである。

さて, 短肝静脈を処理した後, 右肝静脈の肝外処理 に際して問題となるのは，右䀒静脈の下大静脈流入部 周囲に勒帯様の結合組蟣が存在することである。この

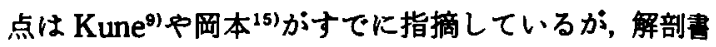
に見られる下大静脈勒帯と言ら用語を用いて，同部の 処理法を詳述した論文は見当らない. 右肝静脈の肝外 処理をする際の下大静脈勒帯の処理法の要点は, いき なりこれを切離しよ5とせず，下大静脈右側壁を左方 八王排しながら下大静脈勒帯と下大静脈を副離し，結 禁切離することである. 下大静脈勒带を下大静脈から 剥離するのではなく，下大静脈を下大静脈靶帯から䟝

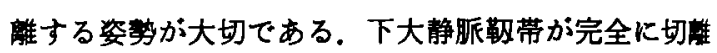
されると, 同部の下大静脈は右方に突出し, 以後の右 肝静脈の処理は容易である. Nakamura ら 脈の肝外処理には右肝静脈の第一分岐まで1cm が必 要で, 解剖学的研究から67.4\%は下大静脈流入部より $1 \mathrm{~cm}$ 以内に分岐がないので肝外処理が可能としてい る.しかし，我々の経非では右肝静脈の分岐のために 右肝静脈の肝外処理が困難となった例はなく，下大静 脈勒帯の処理こそが肝外処理の要点であると考えてい る. 事実, 下大静脈勒带を肝外で処理するよ5になっ てからの右肝静脈の䏕外処理率は $88 \%$ と右肝静派の分 岐からみた Nakamura の67.4\%よりはるかに高率と なっている.

\section{VI. 結 論}

肝切除に際して，右肝静脈を肝外で処理するために は，下大静脈勤帯の切離が必須である。これを意識し て切離するよ5にしてからの25例では88\%に肝外処理 が可能となった。

本論文の要旨は第 45 回日本臨床外科学会総会(広島)にて 幕内が発表した。尚。本研究には厚生省がん研究助成金の助 成を受けた。

\section{文 献}

1) Anson, B.J. and Maddock, W.G.: Callander's surgical anatomy. 4th ed., p. 443 , Saunders, Philadelphia, 1958.

2) Couinaud, C.: Le foie. Études anatomiques et chirurgicales. Masson et Cie, Paris, 1957.

3) Bengmark, S.: Liver surgery. Prog. Surg., 6:1 $-59,1968$.

4) Longmire, W.P. Jr. and Cliveland, R.J.: Surgical anatomy and blunt trauma of the liver. 
Surg. Clin. North Am., 52: 687-698, 1972.

5) Starzl, T.E., Bell, R.H., Beart, R.W., et al.: Hepatic trisegmentectomy and other liver resections. Surg. Gynecol. Obstet., 141: 429 $-437,1975$.

6) Adson, M.A. and Beart, R.W. Jr.: Elective hepatic resections. Surg. Clin. North Am., 57 : $339-360,1977$.

7) Ong, G.B.: Techniques and therapies for primary and metastatic liver cancer. Curr. Probl. Cancer, $2: 1-48,1977$.

8) Linder, R.M. and Cady, B. : Hepatic resection. Surg. Clin. North Am., $60: 349-367,1980$.

9) Kune, G.A.: The anatomical basis of liver surgery. Aust. N.Z.J. Surg., 39 : 117-126, 1969.

10) Brasfield, R.D.: Major hepatic resection for malignant neoplasms of the liver. Ann. Surg., 176 : 171-177, 1971 .
11) Fortner, J.G., Kim, D.K., Maclean, B.J., et al.: Major hepatic resection for neoplasia. Ann. Surg., 188: 363-370, 1978.

12) Blumgart, L.H., Drury, J.K. and Wood, C.B. : Hepatic resection for trauma, tumor and biliary obstruction. Br. J. Surg., 66: 762-769, 1979.

13) Starzl, T.E., Koep, L.J., Weil, R. III., et al. : Right trisegmentectomy for hepatic neoplasm. Surg. Gynecol. Obstet., $150: 208-214,1980$.

14）長谷川博, 山崎 晋,三陯 潔：広範囲肝切除の基 本手技。臨床外科， $32 ： 1521-1527 ， 1977$ 。

15）岡本英三: 払大肝右葉切除㭪, 臨床外科, 31 : 1291-1296, 1976.

16) Nakamura, S. and Tsuzuki, T.: Surgical anatomy of the hepatic veins and the inferior vena cava. Surg. Gynecol. Obstet., 152 : 43-50, 1981. 